\title{
Forestry education and training in Bangladesh ${ }^{1}$
}

\author{
by V.J. Nordin ${ }^{2}$
}

\section{Introduction}

This presentation provides a summary review of forest education and training in Bangladesh. It reveals Bangladesh initiatives to become self-sufficient in forest education to train and educate the professionals, technicians, and vocational personnel required in forestry, a sector which is so significant for the well-being of the people of Bangladesh.

\section{Background}

Bangladesh has a total area of about 55,600 square miles of which 5,500 square miles $(9.9 \%)$ is covered by forest under some degree of state management. The population of more than $120,000,000$ is one of the densest in the world and, apart from afforestation of newly created delta lands, the possibility of adding to the area of the forest estate is limited. Canada, with a population of approximately $27,000,000$, has a land area of $3,466,182$ square miles with a forest area of $1,485,000$ square miles (43\%).

Increased forest productivity in Bangladesh, therefore, must come through more intensive and efficient management of both state forest areas and village homestead woodlots. Threequarters of the nation's forest products comes from these homestead woodlots. Accordingly, the Bangladesh Forest Department has initiated forest extension services to help the people to improve the productivity of these private lands.

Effective management requires trained personnel in all technician and professional categories of the Forest Service. Bangladesh, however, has lacked adequate forest educational capabilities to train essential staff.

Prior to the Second World War, forestry training was concentrated at Dehra Dun in India. After Pakistan became a sovereign state, forestry training of technicians and professionals was centred at Peshawar in West Pakistan. Subsequently, the Bangladesh Forest School was established at Sylhet in 1948 to train Forest Guards and Foresters. In 1964, the Bangladesh Forest College was started at Chittagong to produce Forest Rangers and, in 1976, the Institute of Forestry, Chittagong University, was initiated to educate professional forest officers.

In 1976, the Government created a vocational training centre at Kaptai offering instruction in logging and equipment maintenance, sawmilling and sawdoctoring, agroforestry and extension. In 1985, the Forest School at Rajshahi was inaugurated, with a two-year Diploma in Forestry program, a curriculum similar to the one at the Bangladesh Forest School, Sylhet.

Currently, there is a shortage of qualified teachers at professional university and technician levels, and library facilities and education materials and aids, while improved, remain inadequate. Further, existing physical plant facilities are insufficient to accommodate training requirements. Another major constraint to forestry education in recent years has been political disruption which has severely impeded

\footnotetext{
${ }^{1}$ The writer is indebted to Orhan Baykal, The World Bank, Washington, DC, and to Bruce A. Ross, International Consulting Division, Chemonics, Ltd., Washington, DC, for reviewing this manuscript.

${ }^{2}$ V.J. Nordin and Associates Ltd., Ottawa, Ontario, Canada.
}

progress of all university students, including those studying forestry.

\section{Forestry Issues and Problems}

Coupled with this situation of inadequate forestry education capacities, there is a serious shortage of trained manpower at all professional, technical and vocational levels to deal with the many significant forestry problems facing the nation. There is a need for a systematic analysis to relate present and future forestry programs to human resources requirements in the short, medium, and long terms. Such analysis is essential for effective manpower planning.

The Sundarbans, the largest mangrove forest in the world, is being over-exploited in both timber, fish, and wildlife resources. This government-owned forest needs an environmentally sound, intensified management of its multiple resources to ensure sustainability and optimum production from its rich assets.

The coastal zone of Bangladesh is $710 \mathrm{~km}$ long extending from the Sundarbans Reserved Forest to the Burmese border. Since 1965, the coastal wetlands and low-lying offshore islands have been planted with mangroves to minimize the effects of recurring cyclones and storms, to stabilize accreted lands, to provide additional lands for agriculture, and to yield forest products, particularly wood for fuel. Some constraints complicating the effective management of coastal zone plantations include the pilferage of fuelwood from existing plantations, overgrazing by domestic livestock, and overfishing that may adversely affect fish stocks as well as wildlife. Additionally, the productivity of extensive coastal mangrove plantations is being degraded by a severe infestation of stem borer insects.

Homestead forests are important because they produce about $75 \%$ of wood consumption, primarily for fuel. Overcutting of homestead forests needs to be addressed including the enhancement of village afforestation, strip plantations, and the integrated training of farmers and women. The merging of the traditional and social aspects of forestry with maximum participation by rural people is an important objective for Bangladesh.

There are other issues in the forestry sector (e.g., increased regeneration and improved management of hill tracts) but a general need is to afforest all possible vacant public, private and industrial lands and to integrate trees with farming, traditional land use and the environment. A crucial need is to motivate people living around government-owned forests to participate in the conservation of the resources. However, there is little incentive for people to protect the trees. Further, technically excellent management plans are obstructed when unlawful acts undermine forest protection efforts.

\section{Existing Forest Education and Training Facilities \\ Bangladesh Forest School, Sylhet}

This school was established in 1948 when it offered a oneyear course leading to the Certificate in Forestry, with an intake of 15 students annually. Following enlargement in the early $1980 \mathrm{~s}$, accommodation was provided for 70 students 
enroled in a two-year Diploma in Forestry program to qualify as Foresters, and 30 Forest Guards who took a three-month curriculum.

This facility, in its present state, can train about 50 Forest Guards annually, twenty-five students in each of two fourmonth sessions. The school is inadequate, however, for a new proposed three-year program for Foresters following 10 years of secondary school, and consideration is being given to training foresters at a new location in Chittagong where teaching resources and infrastructure can be maximized in cooperation with other educational institutions including the University and the Bangladesh Forest College.

\section{Bangladesh Forest College, Chittagong}

This College was founded in 1964 on the campus of the Bangladesh Forest Research Institute, with an intake of 15 Forest Ranger students every second year following a two-year curriculum leading to the Diploma in Forestry. In 1977, the College was affiliated with Chittagong University to provide a B.Sc. (Pass) Forestry degree. The entry requirement was raised from the Higher Secondary School Certificate to the degree of B.Sc. (Pass) in Natural Science.

By 1985, the recruitment of Forest Ranger trainees was discontinued and the College has since served as an in-service training institute to instruct Forest Department staff in a wide range of topics. In 1984-85, new academic and residual buildings were constructed and a substantial quantity of books and equipment were supplied by UNDP/FAO. However, some laboratories are not equipped and College facilities are under-utilized.

\section{The Forest School, Rajshahi}

This school was begun in 1985 to accommodate 50 students, with an output of 25 per year, following the twoyear Diploma in Forestry program for Foresters. However, with the recent government decision that forester training should follow a three-year program, the school can no longer accept an intake of 50 students.

The School's current mandate, therefore, is to provide short courses of specialized instruction to Forest Department staff in forest extension and social forestry, topics pivotal to forestry development in Bangladesh.

\section{Forest Development and Training Centre, Kaptei}

This Centre was established in 1976 to train vocational workers and labourers. The objective of the Centre is to provide vocational training for a yearly output of 300 trainees as well as to produce a pool of instructors in:

1. Basic logging techniques, timber extraction and forest road construction.

2. Operation and maintenance of logging, timber extraction and transport, as well as road building machinery and equipment.

3. Sawdoctoring and mill maintenance.

4. Forestry extension and rural reforestation.

\section{The Institute of Forestry, Chittagong University (IFCU)}

Through its Institute of Forestry, Chittagong University is the only institution in Bangladesh that offers professional education in forestry. The IFCU was established in 1976 as an Institute within the Faculty of Science, with a separate Governing Board on which the Forest Department and private sector are represented.

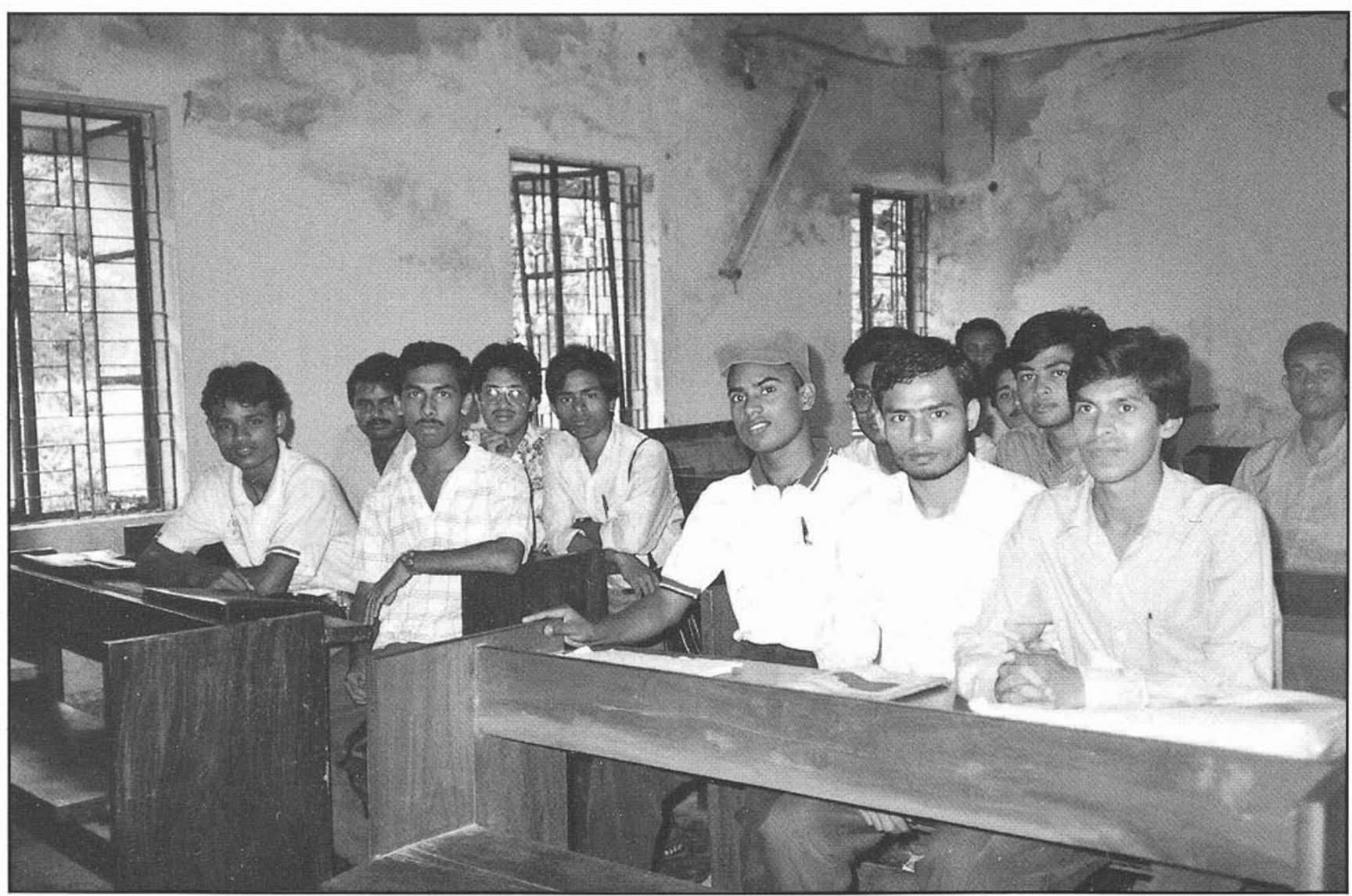

Figure 1. First year students in class, Institute of Forestry, Chittagong University. 
The first class of graduates received their B.Sc. (Honours) degrees in 1984 and since that time, 91 forestry professionals have graduated. The intake of students in 1991 was 45, 40 national and 5 foreign students (Figure 1). There is a teaching staff of 15 (1 Ph.D., 5 M.Sc., 4 B.Sc., 3 pursuing Ph.D. degrees and 2 on M.Sc. programs).

\section{Current and Future Development}

\section{Technical Training}

Through further World Bank/UNDP/FAO support, there are plans to up-grade the school at Sylhet to provide teaching and accommodation facilities for 50 students and the training of 100 Forest Guards annually in two, four-month sessions. A national consultant will refine the four-month curriculum.

In addition, a new forestry school at Chittagong is proposed for the training of foresters including academic facilities, housing for students and staff, laboratory and transport equipment, and a national consultant to delineate a three-year curriculum.

\section{Professional, University-level Training}

Concerned about environmental pollution and the degradation of watersheds, forests, and other natural resources, and the lack of manpower to monitor, evaluate, formulate policies and manage these resources in an environmentally sustainable manner, the Government of Bangladesh through its Ministry of Environment and Forests, has requested Chittagong University to reorganize the Institute of Forestry into the Institute of Forestry and Environmental Science. This proposal has been formally approved by the University.
The new Institute will have one undergraduate professional curriculum combining the fields of forestry and environmental sciences to accomplish a comprehensive resource/environmental training for B.Sc. graduates.

IFCU is well advanced in its plans to establish a masters degree program. Such a program with an accompanying research component will also improve the quality of the undergraduate curriculum and facilitate research opportunities for postgraduate students and staff. Further, IFCU's prospects to establish links and cooperation with other academic institutions in and outside Bangladesh will be reinforced through postgraduate teaching and research.

New academic and student accommodation buildings are nearing completion (Figure 2) and these and additional proposed construction will improve the environment for undergraduate studies and provide a suitable infrastructure for the proposed masters degree program.

To ensure the development of a world-class master's degree program, fellowship support is planned for academic staff to obtain advanced degrees in fields of specialization that remain to be strengthened. Further, to improve the practical element in undergraduate teaching and provide field facilities for postgraduate studies and ancillary research, IFCU has proposed the acquisition of a field station/training forest.

Additional plans include the assistance of international consultants to advise on undergraduate and postgraduate curricula as well as the establishment of fellowships to encourage superior students to undertake postgraduate training in the new M.Sc. program.

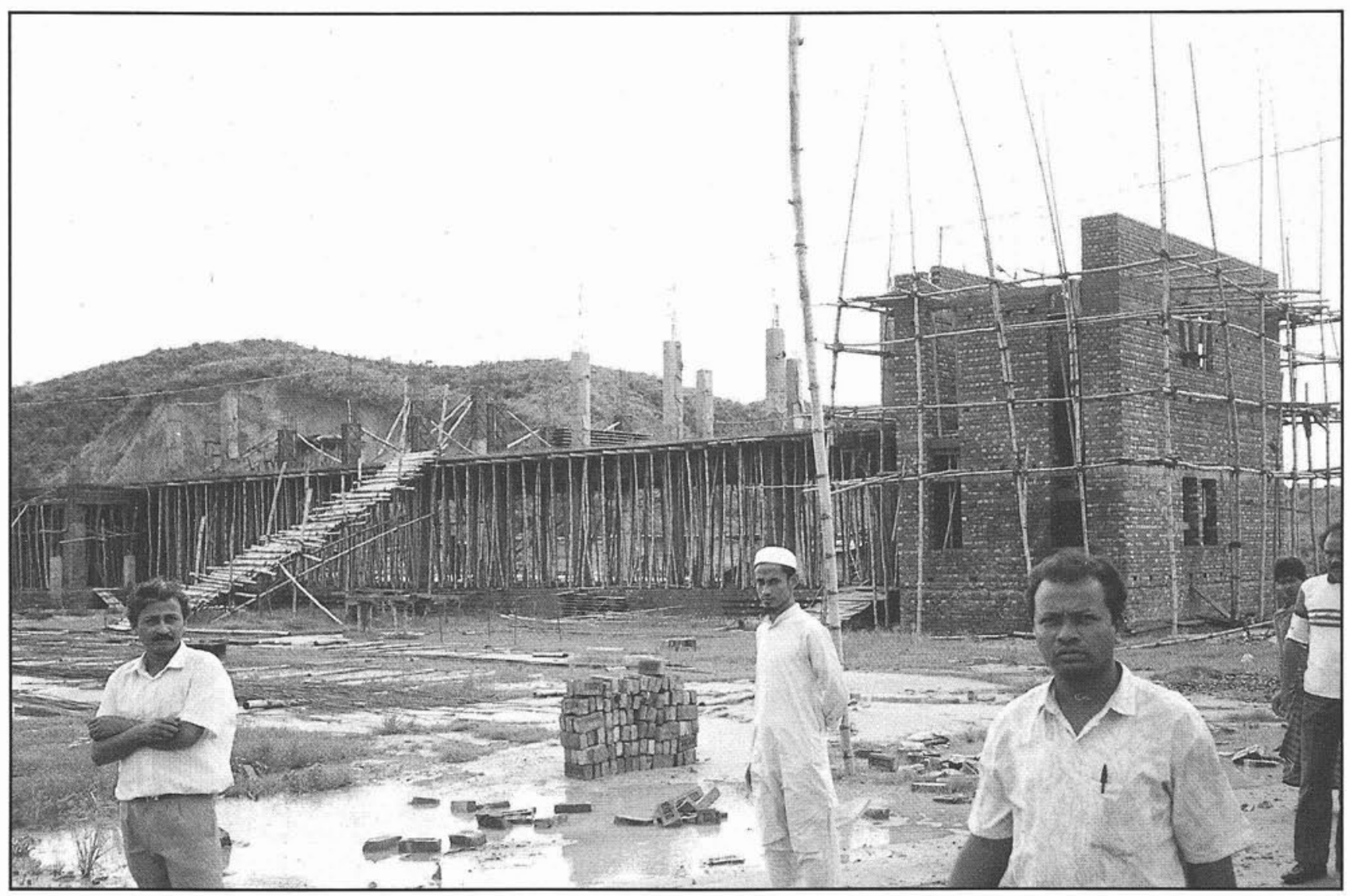

Figure 2. New Academic Building under construction, Institute of Forestry, Chittagong University. 


\section{Conclusions}

The Government of Bangladesh, with the support of the world community, is making substantial progress in developing professional, technical and vocational expertise in forestry. This progress is essential for the Nation's societal needs and will also enable Bangladesh to collaborate internationally in the sector for the benefit of the country and its people.

\section{References}

Ampongan, Antonio C. 1990. Draft Final Report, Assistance to the Forestry Sector of Bangladesh-Phase II. FAO/UNDP Working Paper No. 27. Rome.
Anonymous. 1990. Brochure, Institute of Forestry, Chittagong University, Chittagong.

Marsater, B. 1990. Curriculum and teaching materials: Forest College. FAO/UNDP Draft Working Paper 28. Rome.

Redhead, J.F. 1985. Forestry education, training and institutional development in Bangladesh. FAO/UNDP Field Document No. 6. Rome.

The World Bank. 1991. Bangladesh Forest Resource Management Project, Preparation Mission. FAO Investment Centre, FAO/World Bank Cooperative Program. Rome.

\section{STORA \\ Stora Forest Industries Limited}

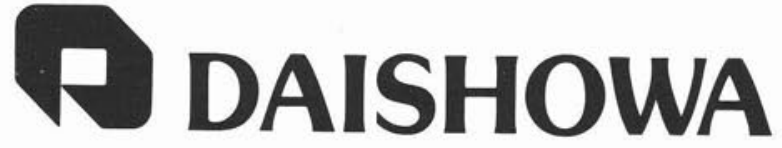

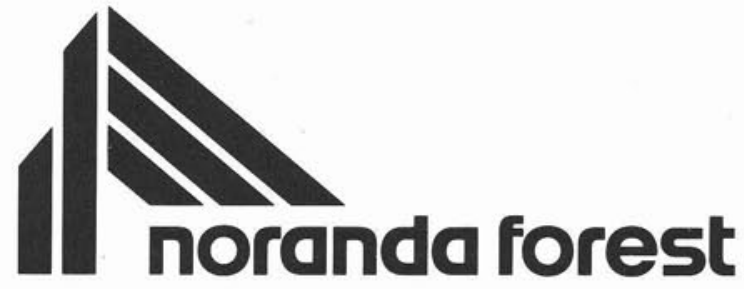

Weldwood 